\title{
Gênero e política no pensamento de Maquiavel
}

Gender and politics in the thought of Machiavelli

Apesar de parecer exclusivamente masculino, o mundo das obras políticas de Maquiavel, onde os homens competem na arena da história, é, na verdade, dominado, ou pelo menos continuamente ameaçado nos bastidores, por figuras femininas de imenso poder, mal percebidas e espectrais. Em aspectos cruciais, a competição entre os homens acaba por ser sua luta comum contra esse poder. O feminino constitui “o outro" de Maquiavel, em oposição à masculinidade e à autonomia em todos os sentidos: às condições de homem, de adulto, de humano, bem como à política.

Essa afirmação pode ser surpreendente, pelo menos por duas razões. Em primeiro lugar, as mulheres praticamente não aparecem nas obras políticas. Elas são quase totalmente confinadas ao teatro e à poesia de Maquiavel, retratando a vida privada ou mundos de fantasia. Com exceção de algumas figuras históricas, como a Lucrécia da antiguidade e a moderna Catarina Sforza, nas obras políticas, as mulheres primam pela ausência. Assim, na maior parte, os comentadores com preocupações políticas ignoraram as questões relacionadas a papéis sexuais e família, assim como as obras literárias, enquanto os estudiosos de literatura não deram atenção mais contínua a suas implicações políticas.

É professora emérita do Departamento de Ciência Política da Universidade Califórnia (Berkeley, Califórnia, Estados Unidos). É autora do livro The concept of representation (1967), dentre outros.

Do original "Because of women...," publicado como capítulo 5 do livro Fortune is a woman: gender and politics in the thought of Niccolò Machiavelli (1999, $2^{\text {a }}$ edição). Direitos autorais concedidos pela University of Chicago Press. Tradução de Roberto Cataldo Costa. Revisão da tradução por Flávia Biroli. 
Este artigo analisa em detalhe as imagens de Maquiavel sobre mulheres e relações entre os sexos, a partir dos textos, de modo que sua importância política possa ser explorada posteriormente.

Contudo, quando se começa a observar as imagens que Maquiavel produziu das mulheres, surge uma segunda razão para surpresa diante da afirmação de que por trás do mundo aparentemente masculino da disputa política assoma um poder feminino oculto: nada é mais marcante nas declarações explícitas de Maquiavel sobre as mulheres do que o seu desprezo pelo "sexo frágil". Como contrapartida ao seu conceito de virtù, nenhum epíteto é mais frequente ou mais poderoso no vocabulário de insultos de Maquiavel do que "afeminado". O que os homens e os Estados devem evitar a todo custo é se parecer com as mulheres. É claro que "afeminado" não é o mesmo que "feminino" e, em princípio, poder-se-iam condenar os homens afeminados sem desmerecer as mulheres. Mas o desprezo de Maquiavel para com elas é manifestado repetidamente, e o que ele condena na afeminação é precisamente o que considera típico das mulheres. As mulheres são burras, medrosas, fracas, indecisas e dependentes. Elas são infantilmente ingênuas e facilmente manipuláveis. Como afirma o sacerdote em A mandrágora, "todas as mulheres carecem de cérebros"; se por acaso uma delas for, como exceção, inteligente o bastante "para dizer duas palavras", isso já é suficiente para "torná-la famosa, pois em terra de cego quem tem um olho é rei" (Machiavelli, 1965, Mandragola, ato 3, cena 9, p. 800-801). E o próprio Maquiavel parece concordar. Por exemplo, ao discutir como as conspirações são traídas, ele classifica as mulheres ao lado de meninos imaturos e outras "pessoas tolas" em quem não se deve confiar (Machiavelli, 1965, p. 434). Além disso, as mulheres são amedrontadas e covardes, incapazes de se defender. $\mathrm{O}$ esperto Ligúrio observa que "todas as mulheres são medrosas" (Machiavelli, 1965, Mandragola, ato 3, cena 2, p. 794), e Calímaco adverte, ele próprio: "Não te acovardes como uma mulher" (Machiavelli, 1965, Mandragola, ato 4, cena 1, p. 805). Mais uma vez, Maquiavel parece concordar; por exemplo, ao se opor a fortalezas, ele cita com aprovação evidente o comentário de desprezo dos espartanos sobre os muros de Atenas, de que esses muros seriam, de fato, "esplêndidos... Se protegessem mulheres" (Machiavelli, 1965, p. 397); os próprios espartanos preferiam confiar no "valor [virtù] de cada homem" (Machiavelli, 1960-1965, I, p. 355). Pelo menos em um contexto militar, as mulheres, como as crianças e os idosos, são "pessoas inúteis [inutile]" (Ma- 
chiavelli, 1965, p. 407); assim como os eclesiásticos, elas, "por necessidade", têm que depender dos braços de Outros (Machiavelli, 1960-1965, I, p. 366; ver também 1965, p. 1078).

No entanto, ao mesmo tempo em que são desprezíveis, tolas e fracas, de alguma forma as mulheres também possuem poderes misteriosos e perigosos; constituem uma ameaça aos homens, tanto no plano pessoal quanto no político. Observando particularmente a ficção de Maquiavel, pode-se dizer que esses poderes misteriosos e perigosos parecem ser de dois tipos distintos, um correspondendo a mulheres jovens ou solteiras, ou filhas, e outro, às mulheres mais velhas, esposas, mães, matronas. Muitas vezes, os dois tipos de mulheres aparecem em pares conectados: filha e mãe, serva e rainha, ou bela virgem que se transforma em esposa megera.

As mulheres jovens ou filhas são, quase sem exceção, apresentadas como objetos sexuais, no sentido próprio do termo: são lindas, desejáveis como posses, fontes potenciais de grande prazer para os homens. De alguma forma, são simultaneamente virginais ou castas e apaixonadas ou potencialmente dispostas à entrega sexual. Mas são passivas, e mal são pessoas. Não têm desejos ou planos próprios, nem qualquer iniciativa de ação deliberada, não são agentes importantes no mundo. São objetos de desejo, conquista ou posse dos homens. Como objetos desejáveis, no entanto, têm muito "poder", de um tipo que move e segura os homens; sem pretender nem realmente fazer nada, são a força central que faz com que a trama avance. Seu poder é como o do ouro, ou, como diz o frei em A mandrágora: "quem lida com elas tem vantagens e aborrecimentos, ao mesmo tempo. Mas se sabe que não há mel sem moscas" (Machiavelli, 1965, Mandragola, ato 3, cena 4, p. 796).

Lucrécia, a "heroína" de $A$ mandrágora, não é totalmente desprovida de personalidade ou caracterizações, porém, o que aprendemos acerca dela é incoerente e confuso. Por um lado, ela é o modelo de virtude e castidade e assim deve ser para fins da trama, para torná-la tanto desejável quanto inacessível. Assim, sua "beleza e [suas] maneiras" são tão exemplares que os homens que ouvem falar dela ficam "encantados"; ela é uma mulher "prudente e boa", "muito casta e completamente estranha às coisas do amor" (Machiavelli, 1965, Mandragola, ato 1, cena 1, p. 780; ato 3, cena 9, p. 800; ver também ato 4 , cena 1, p. 804). Ela se ajoelha para rezar por horas à noite e já defendeu com êxito sua virtude contra os avanços de frades lascivos (Machiavelli, 1965, Mandragola, ato 2, cena 6, p. 790; ato 3, cena 2, p. 794). 
Sua personagem é tão pura e firme que nenhum servo em sua casa se atreveria a conspirar contra ela ou receber suborno; seu marido tem certeza de que ela jamais consentiria em qualquer esquema ilícito (Machiavelli, 1965, Mandragola, ato 1, cena 1, p. 780; ato 2, cena 6, p. 792). Na verdade, ao ouvir falar do plano de Ligúrio, ela se opõe com vigor ao "pecado" e à "vergonha" nele contidos, bem como à ideia de tirar a vida de um homem inocente (Machiavelli, 1965, Mandragola, ato 3, cena 10, p. 801; ato 3, cena 11, p. 803). Em suma, ela é, como diz Ligúrio, “virtuosa, amável e apta a governar um reino" (Machiavelli, 1965, Mandragola, ato 1, cena 3, p. 783). No entanto, não só esse modelo de virtude acaba por ser muito maleável nas mãos do marido tolo, da mãe má e de um padre corrupto - tanto que ela concorda em cometer um pecado óbvio (que ainda pode estar dentro dos limites da credulidade) - como ela também é transformada, depois de uma noite com seu amante, em uma decidida e competente adúltera que, sem nenhuma ponta de consciência, sabe exatamente como providenciar as coisas para que ela e o amante possam continuar a enganar o marido enquanto ele viver. Como caracterização de uma pessoa real, uma pessoa em si mesma, isso é difícil de aceitar. Como descrição de um objeto de desejo e ação, cujas características contraditórias fazem avançar a trama, no entanto, há um sentido bastante óbvio.

É claro que essa imagem um pouco incoerente da heroína romântica não é exclusiva de Maquiavel; na verdade, é material de muitas comédias. No entanto, a ambiguidade do autor em questão em relação a Lucrécia é mais profunda do que a convenção. Há o tópico, já levantado, de sua relação com a Lucrécia antiga, histórica, sugerindo que $A$ mandrágora desenvolve como farsa, em relação à vida familiar, aquilo que Tito Lívio narra como tragédia heroica em relação à vida política romana na antiguidade. A Lucrécia moderna é um modelo de virtude, mas facilmente corrompido; a antiga, embora saiba que "apenas o meu corpo foi violado... meu coração é inocente", ainda assim se mata como exemplo público e insiste em receber sua "punição" (Livius, 1967, I, 58, 1. 7, 10).

No Livro 3 dos Discursos, Maquiavel cita a Lucrécia antiga como ilustração do perigo que as mulheres constituem para os governantes de um Estado, mesmo que seu único crime tenha sido ser vítima de um estupro (Machiavelli, 1965, p. 489). Na verdade, Maquiavel chega a dizer que a derrubada dos Tarquínios resultou não do estupro de Lucrécia - um mero incidente 
desencadeador, mas de violações tirânicas da lei por parte do rei (Machiavelli, 1965, p. 427). Por que, então, ele a cita como exemplo do perigo feminino? Ela é uma agente da história ou não? E quando o Ligúrio de A mandrágora, cuja semelhança com o próprio Maquiavel já observamos, diz que a Lucrécia moderna é "apta a governar um reino", pode-se pressupor que Maquiavel a considere assim?

A heroína de outra peça de Maquiavel, Clízia, a jovem que os outros personagens disputam, é tão "objeto" que jamais aparece no palco nem toma qualquer atitude. ${ }^{1}$ Contudo, também ela é perigosa. Na verdade, Clízia expressa de forma muito poderosa um tópico maquiavélico bastante frequente: o de que o amor é uma guerra, uma luta pela dominação. Clízia é uma tradução bastante próxima da Casina, de Plauto, mas por isso mesmo nos permite tratar daquelas passagens específicas em que Maquiavel diverge do original. Central a essas divergências, como apontou Martin Fleischer, é o fato de que Clízia aumenta em muito o tema do conflito já presente na peça de Plauto, particularmente a metáfora do amor como luta militar entre os sexos (Fleischer, 1966, p. 371). Um servo fala de fazer amor usando termos como "atacar" e "enfrentar forte resistência"; um velho se preparando para fazer amor com uma jovem fala de "mobilizar" suas "brigadas", e acrescenta: "Quando se vai armado à guerra, vai-se com coragem redobrada" (Machiavelli, 1965, Mandragola, ato 5, cena 1, p. 857; ato 4, cena 5, p. 852). O jovem amante recita um monólogo sobre o tema, sem paralelo em Plauto, mas provavelmente derivado de Ovídio:

Certamente, o homem que disse que o amante e o soldado são iguais disse a verdade. O general quer que seus soldados sejam jovens; as mulheres não querem que seus amantes sejam velhos. É repugnante ver um velho soldado, e mais repulsivo é vê-lo apaixonado. Os soldados temem a raiva do seu comandante; os amantes não temem menos a de suas damas. Os soldados dormem no chão, ao relento; os amantes [sob as janelas de suas amadas]. Os soldados perseguem seus inimigos até a morte; os amantes, seus rivais. Os soldados, nas noites mais escuras em pleno inverno, passam pela lama, expostos a chuva e vento, para realizar algum empreendimento que lhes trará a vitória; os amantes

Isso, entretanto, é comum no início da Commedie Erudite e era uma prática comum no teatro romano (Flaumenhaft, 1978, p. 74, n. 79). 
tentam, de maneiras semelhantes e com sofrimentos semelhantes e maiores, conquistar a quem amam. Na guerra como no amor, é necessário sigilo, bem como fidelidade e coragem. Os perigos são os mesmos e, na maioria das vezes, os resultados são os mesmos. O soldado morre em uma vala e o amante morre em desespero (Machiavelli, 1965, Clizia, ato 1, cena 2, p. 829). ${ }^{2}$

O jovem está deprimido ao fazer esse discurso, por isso não considera a possibilidade de vencer nem de traçar o único paralelo que resta: a vitória também é como conquistar, vencer um prêmio. A peça de Plauto também apresenta um monólogo sobre o amor, mas falado pelo velho e não pelo filho, e sem referências a temas militares; em vez disso, suas metáforas centrais tratam de alimentos e de comer (Plautus, 1985, p. 313-314; cf. 310-311).

Clízia tampouco é única em suas metáforas militares; o tema do amor como guerra é comum em obras literárias. Em A mandrágora, ao sair com seus companheiros para levar a cabo os eventos que irão colocar Calímaco na cama de Lucrécia, Ligúrio diz:

Serei capitão e convocarei o exército para a batalha. No chifre direito, Calímaco estará no comando; eu, no esquerdo, entre os dois chifres estará o Juiz aqui; Siro será a retaguarda e reforçará qualquer esquadrão que recue. O grito de guerra será São Cuco. ... Marchemos e façamos nossa emboscada nesse canto (Machiavelli, 1965, Mandragola, ato 4, cena 9, p. 813; ver também Machiavelli, 1965, “[Golden] Ass”, IV, 1. 105-114, p. 760-761).

Em uma "Serenata" evidentemente baseada nas Metamorfoses de Ovídio, um jovem amante chora e se rende diante da porta de sua amada:

Você venceu, Anaxarte. Estou feliz de morrer, para que possas ... levar a vitória. Enfeita seus templos com louros verdes; comemora o seu triunfo na guerra que travei contra você (Machiavelli, 1965, “Serenade”, 1. 161-176, p. 1019).

Como sugerem essas linhas, a guerra entre os sexos é complexa, pois mesmo quando o homem consegue conquistar a mulher que busca, pode-se revelar que ele foi a vítima no final das contas, superado por ela e pelo

Ver também, os Amores, de Ovídio (I, 9, I. 1-20). 
poder do amor. O amor está relacionado a dominação e posse, mas isso não precisa significar que os homens sejam sempre os conquistadores, e as mulheres, as possuídas. Na verdade, há muito que se deliciar com algumas das imagens de servidão romântica de Maquiavel, que relembram baladas medievais tardias sobre o amor cortês. Ele insiste na torpeza da submissão do amante, na extensão de seu tormento.

Calímaco, em A mandrágora, diz que está "queimando de vontade de estar com" sua dama, que nunca tem qualquer paz e que preferiria morrer a continuar nesse estado (Machiavelli, 1965, Mandragola, ato 1, cena 1, p. 780). E, em monólogo, expressa a intensidade de seu desejo:

Eu sinto como se meu corpo inteiro, da sola dos pés até a cabeça, estivesse errado [tutto altare (totalmente alterado)]: minhas pernas tremem, meus órgãos vitais estão abalados, meu coração foi arrancado do peito, meus braços perdem força, minha língua fica em silêncio, meus olhos ficam deslumbrados, meu cérebro gira.

Tudo isso é para uma única ocasião com sua amada, embora ele diga para si mesmo:

Quando a tiveres, o que significará? Vais reconhecer teu erro, vais te arrepender do trabalho e da preocupação por que passastes. Não sabes o quão pouco um homem encontra de bom nas coisas que desejava, em comparação com o que espera encontrar? (Machiavelli, 1965, Mandragola, ato 4, cena 1, p. 805). ${ }^{3}$

Em Clízia, os amantes sentem uma angústia comparável em sua servidão um para com o outro e diante do amor, com suas temidas "armas" (Machiavelli, 1965, Clizia, ato 1, cena 1, p. 828; canzone antes do ato 2, p. 830; ato 3, cena 2, p. 838-839).

As mesmas notas soam, de forma mais exagerada, em uma das canções de carnaval de Maquiavel, na qual amantes incorrigíveis são apresentados em sua "lamentável tristeza", situados "no centro profundo do inferno". Eles foram para lá voluntariamente, ao que parece, porque preferiam os tormentos dos demônios às "aflições" de seus amores. A canção abunda em termos como "regra", "poderes", "fuga", "soluços e suspiros", "crueldade”, "tormento"

Ver, também, Machiavelli (1965, Mandragola, ato 1, cena 3, p. 785; ato 2, cena 6, p. 793; 1960-1965, VIII, p. 93). 
e "servidão" (Machiavelli, 1965, "Carnival song by lovers", 1. 1-14, p. 879). Em suas próprias cartas pessoais, Maquiavel também descreve o amor como uma força diante da qual um homem se torna impotente ou deliciosamente subjugado. Amor atira com seu arco e flecha, "possuído de ira e fúria, a fim de mostrar seu poder imponente", o qual Maquiavel é forçado a "admitir e reconhecer”. Ele está preso por

correntes tão fortes que [está] totalmente desesperado por [sua] liberdade. Não cons[egue] pensar em alguma maneira de [s]e desacorrentar; e mesmo se a casualidade ou algum estratagema humano abrisse a [ele] alguma maneira de sair delas, talvez [ele] não gostasse de aproveitá-la; de tão doces, sejam leves ou pesadas, que [ele] considera essas correntes (Machiavelli, 1965, p. 960-961). ${ }^{4}$

É contra esses tormentos perigosos, mas sedutores - os poderes das jovens como objetos sexuais - que se dirige a maioria das advertências explícitas de Maquiavel em relação a mulheres na política. Embora raramente discutidos pelos comentadores, esses alertas são repetidos e, às vezes, com muita força. "Como cai um Estado por causa das mulheres", anuncia o título de um dos capítulos nos Discursos. Nele, em meio a exemplos de mulheres jovens que, sem nada fazer de concreto, motivam homens a causar problemas políticos, Maquiavel escreve:

As mulheres já produziram muita destruição, grandes prejuízos já causaram àqueles que governam as cidades, e ocasionaram muitas divisões entre eles. (...) Digo, então, que os príncipes absolutos e governadores de repúblicas devem levar muito em conta essa questão (Machiavelli, 1965, p. 488-489).

Na narrativa esquemática de Maquiavel, tomada emprestada de Políbio, sobre como os Estados passam por um ciclo de formas políticas, a degeneração dos últimos "herdeiros" em relação a seus virtuosos “ancestrais” já está atribuída a ambição, avareza e "violência contra as mulheres" (Machiavelli, 1965, p. 198)5. E, embora, por vezes, Maquiavel justifique o primeiro desses

4 Ver também outra cartas a Vettori, em Machiavelli (1965, p. 960-961; p. 937, p. 946).

5 Cf. Polybius (1889, p. 458-466), que inclui na lista de infrações "a apropriação dos meninos", omitida por Maquiavel. 
vícios e até elogie o segundo, quando se trata de relações com as mulheres, o que esse suposto imoralista parece valorizar nos líderes políticos e heróis é a castidade (p. ex., Machiavelli, 1965, p. 476 e 701). Não porque admire intrinsecamente a castidade ou como virtude cristã, mas por causa de seu significado político. Embora represente guerra e dominação, o amor também é, de alguma forma, uma alternativa, hostil, à política; e a conquista sexual pode revelar, mas também ameaça prejudicar, a virtù de um homem. Cosimo Rucellai, segundo aprendemos no início de $A$ arte da guerra, escreveu poemas de amor enquanto esperava por uma chance de ação "superior", isto é, política (Machiavelli, 1965, p. 568).

$\mathrm{Na}$ verdade, o próprio Maquiavel escreve cartas de seu exílio político, vangloriando-se aos amigos de suas aventuras sexuais e romances. Os comentadores parecem concordar que a maioria é imaginária, inventada para a diversão de seus amigos e a sua própria. Ele explica:

Abandonados (...) os pensamentos sobre envolvimentos amorosos que sejam grandes e sérios; não tenho mais prazer em ler as coisas antigas nem em discutir as modernas; todas são transformadas em conversas brandas, pelo que agradeço a Vênus e a todo Chipre (Machiavelli, 1965, p. 946).

O contraste lembra aquele apresentado em $A$ arte da guerra, entre as coisas "fortes e brutas" e as "delicadas e brandas", entre quem dá abrigo e quem dele depende (Machiavelli, 1965, p. 570). Considerando-se que as mulheres significam as coisas brandas, delicadas e dependentes, parece que a associação com elas ameaça contaminar um homem com essas qualidades. Embora possa ser conquista, o amor transforma o mulherengo em um homem fraco e pouco viril, incapaz de controlar suas paixões e distraído de outras preocupações "superiores". As mulheres representam tempo ocioso para um homem, desvio de energia e uma diminuição de sua guarda.

As aventuras pessoais a que aludem as cartas de Maquiavel são de dois tipos, ambos apresentados em uma veia jocosa de camaradagem masculina. A maioria diz respeito à busca romântica de uma jovem arrebatadoramente formosa, à qual ele se dedica de bom grado e por inteiro, como na passagem acima. Mas pelo menos uma dessas histórias, embora igualmente jocosa, tem uma tendência subjacente de horror e repulsa: atraído para as instalações subterrâneas e escuras de sua lavadeira, relata Maquiavel, ali uma mulher se 
ofereceu a ele, que começou a fazer amor com ela, mas quando ele a viu à luz, ela se revelou terrivelmente feia; sua feiura é descrita em detalhes requintados e repulsivos (Tarlton, 1970; Machiavelli, 1960-1965, VI, p. 204-206). Com a guarda reduzida pela sensualidade, ao que parece, um homem está em perigo; a camaradagem masculina envolve o compartilhamento dessas fantasias de aventura e a restauração da distância e do controle sobre as paixões da carne.

Nessa linha, uma alternativa aceitável para a castidade heroica que Maquiavel recomenda para os líderes políticos é uma sexualidade desdenhosa e emocionalmente distanciada, que mantenha a paixão estritamente dentro dos limites e impeça que qualquer brandura infecciosa seja transmitida ao homem. Assim, o Castrúcio de Maquiavel, o único herói importante que, longe de ser casto, é glorificado por suas conquistas sexuais, é admirável justamente porque, para ele, as conquistas não representam autoindulgência, e sim domínio. Já indiquei que Maquiavel apresenta Castrúcio - ao contrário do fato histórico - como alguém que se abstém do casamento por lealdade ao pai adotivo, é a "gratidão filial" superando seu "amor por filhos" (Machiavelli, 1965, p. 553; Whitfield, 1953, p. 13). A fidelidade masculina é oposta à reprodução sexual. E quando Castrúcio é repreendido por um amigo do sexo masculino devido a sua ligação íntima com uma certa jovem - não por sua imoralidade, mas porque "era ruim para ele se deixar tomar por uma mulher" - segundo a descrição, ele responde: "Fui eu que a tomei, e não ela a mim” (Machiavelli, 1965, p. 556).

$\mathrm{O}$ perigo sedutor de jovens mulheres como objetos sexuais, portanto, tem pelo menos dois componentes: ameaça o autocontrole do homem, seu domínio sobre suas próprias paixões, e ameaça infectá-lo com brandura feminina. Exatamente o mesmo risco reside na aquisição de espólios de luxo como resultado de conquista militar: o conquistador que se abandona à sensualidade e à fertilidade de sua conquista será assim aniquilado. Dessa forma, a captura do que Tito Lívio chamou da "fértil e aprazível" Cápua quase destruiu toda a disciplina entre os soldados romanos (Livius, 1967, VII, 38, 1. 5-7). Maquiavel cita Tito Lívio em relação à maneira pela qual “Cápua, um armazém de todos os prazeres, afastou os espíritos cativados dos soldados da lembrança de seu país" (Machiavelli, 1965, p. 381; Livius, 1967, VII, 38, 1. 5; ver também Machiavelli, 1965, p. 1381).

Não é de admirar que os sábios romanos proibissem mulheres nos acampamentos de seu exército e que $A$ arte da guerra, de Maquiavel, siga o exemplo (Machiavelli, 1965, p. 691). 
As mulheres constituem um perigo para conquistadores, príncipes e tiranos; elas são, ao mesmo tempo, causa e sinal de fraqueza e declínio do governante, quando ele não consegue mais controlar seus próprios impulsos ou (como o rei Tarquínio) os de seus filhos - os "herdeiros" que lançam mão da "violência contra as mulheres". Mas há uma terceira razão pela qual as mulheres são um perigo, uma forma a mais de sua ameaça política. Segundo Maquiavel, Aristóteles lista, "entre as primeiras causas da queda dos tiranos, algum dano em alguma questão de mulheres", mencionando como exemplos tanto Lucrécia quanto a antiga Virgínia, cujo abuso sexual levou à queda dos decênviros (Machiavelli, 1965, p. 488-489). Mas o caso do Duque Galeazzo ilustra o argumento de forma mais explícita. Ele gostava de "perverter mulheres nobres" e, em seguida, vangloriando-se, "tornar públicos os seus êxitos"; ele também abusou da própria mãe, a ponto de as pessoas o considerarem responsável pela morte dela. Ele acabou caindo em desgraça porque "desonrou" dois de seus súditos "em questões de mulheres". Por meio desses "danos privados", reforçou a "determinação" política deles de agir contra ele e "libertar seu país" (Machiavelli, 1965, p. 1379).

As mulheres são um perigo para os conquistadores porque, como mostra este exemplo, estão investidas do sentido de honra de outros homens. Cada mulher está vinculada a pelo menos um homem - marido, pai, irmão - cuja honra está em jogo na castidade dela. O governante que não quer ou não consegue deixar em paz as mulheres de seus súditos está brincando com uma das mais perigosas fontes de oposição em potencial. É por isso que o príncipe nunca deve "se apoderar da propriedade nem das mulheres de seus súditos"; os homens aceitam quase tudo, desde que "não sejam privados de propriedade ou honra" (Machiavelli, 1965, p. 67; ver também p. 63). A propriedade é propriedade, mas as mulheres são propriedade e honra.

Pelo mesmo motivo, as mulheres são um perigo não apenas para tiranos, príncipes, e conquistadores, mas também para a vida política saudável de uma república. Elas fragilizam o autocontrole varonil dos cidadãos, assim como o dos príncipes, e tendem a privatizar o cidadão republicano, atraindo-o para fora da praça pública e para dentro do quarto. A primeira "divisão", na cidade de Florença, que tinha permanecido unida em sua virtuosa saúde política inicial mais tempo do que outras cidades italianas, não foi "causada" por duas mulheres, uma "viúva rica" e sua "filha muito bonita" que geraram uma briga de família? (Machiavelli, 1965, p. 1083) As divisões internas, por 
sua vez, tendem a gerar intervenção externa e, assim, destruir a vida autônoma do corpo político.

Maquiavel cita o exemplo da cidade de Ardea, em que a disputa por uma mulher levou a uma divisão tão profunda entre facções que ambos os lados chamaram ajuda externa, e a cidade foi conquistada (Machiavelli, 1965, p. 488-489). Assim, também, a antiga cidade toscana de Chiusi perdeu sua liberdade após um cidadão, cuja honra havia sido violada por uma ofensa à sua mulher, ter chamado os franceses para vingá-la (Machiavelli, 1965, p. 214). ${ }^{6}$

Contudo, aqui começamos a chegar aos perigos mais profundos, mais sinistros, que a feminilidade parece constituir para a vida política e ao poder mais ativo e intencionalmente malicioso das mulheres, exercido não por donzelas atraentes, mas por mulheres mais velhas que são pessoas ativas, mas hostis. As mulheres mais velhas constituem um perigo político ainda maior do que as meninas sedutoras. Para começo de conversa, essas mulheres podem ser tão ambiciosas quanto os homens, principalmente para com suas famílias ou para suas filhas casadouras, de modo que privatizam e tendem a fragmentar a comunidade. Seu poder para explorar o efeito desagregador das questões sexuais assume proporções legendárias. Causou as primeiras divisões internas em Florença. Enfraquece especificamente os laços patriarcais e políticos entre os homens. Tarquínio, o orgulhoso, tomou o poder a pedido de sua mulher ambiciosa, a filha do rei anterior e legítimo. "Movida" pela "fúria" de sua ambição pelo trono, "contra toda a devoção paternal", ela "incitou o marido contra o pai dela para que tirasse sua vida e seu reino" (Machiavelli, 1965, p. 426).

As mulheres mais velhas na ficção de Maquiavel são muito diferentes de suas filhas. Não são sexualmente atraentes nem sedutoras, mas muitas vezes controlam o acesso às jovens, bloqueando ou facilitando os desejos dos homens. A mãe em A mandrágora é apresentada desde o início como conhecedora do mundo e experiente, e corrupta (Machiavelli, 1965, Mandragola, ato 1 , cena 1, p. 780). Ela é caracterizada como "uma vadia” com seu próprio passado duvidoso; ela prontamente aquiesce ao plano de Ligúrio para sua

Maquiavel distorce a história; cf. Livius (1967, 5.33.3); Strauss (1978, p. 318, n. 66). 
filha e até mesmo pessoalmente coloca a menina na cama para o adultério (Machiavelli, 1965, Mandragola, ato 3, cena 9, p. 801; ato 3, cena 11, p. 803). Além de seus próprios antecedentes, a única pista que nos é dada sobre seu motivo para fazer isso é uma máxima que ela enuncia - uma máxima conhecida das obras políticas de Maquiavel: sempre é prudente "escolher a melhor entre as opções ruins” (Machiavelli, 1965, Mandragola, ato 3, cena 1, p. 793). Em Clízia, a mãe faz ainda mais o tipo de uma maquinadora ativa, embora no campo da moralidade convencional, em vez do da corrupção (mas isso é ditado pela trama de Plauto). Enquanto em Casina, a peça antiga, a mãe é uma astuta que vive em conflito com o marido há anos, a mãe de Clízia é uma boa mulher, uma agente da virtude e da ordem. Em vez de aconselhar "a melhor entre as opções ruins", diz ela, "deve-se fazer o que é certo, em qualquer momento", e especialmente "quando os demais estão fazendo o que é ruim" (Machiavelli, 1965, Clizia, ato 2, cena 3).

Contudo, embora ela seja uma agente de moralidade, seus métodos são os da manipulação e do engano. Não há um Ligúrio astucioso nessa peça; em vez disso, a manipuladora bem-sucedida é a própria mãe, que controla o resultado por meio de sua "esperteza bonita" [bello inganno]. No final, ela diz a seu derrotado e humilhado marido, cujas intenções adúlteras frustrou, que foi ela quem "conduziu todos os truques impingidos a você", para fazer com que "recobre o juízo". Nisso, ele concorda em se colocar "nas mãos dela" e se submeter ao seu comando na casa: "Faz o que quiseres, eu estou preparado para não ir além dos limites que estabeleceres" (Machiavelli, 1965, Clizia, ato 5 , cena 3 , p. 861).

Sendo assim, essa mãe, agente da moralidade e da ordem, está, como Lucrécia, "apta a governar um reino"? Ela certamente conduz o resultado dos eventos, recusando-se a se submeter mesmo à fortuna. Em um dado momento, ela e o marido concordaram em deixar a decisão do conflito "para a Fortuna" por meio de um sorteio, mas quando o sorteio vai contra a mãe, ela busca outras soluções (Machiavelli, 1965, Clizia, ato 3, cena 7, p. 845). Nesse momento da peça, Maquiavel insere uma canção, sem qualquer contrapartida em Plauto, sobre o perigoso poder da mulher. "Aquele que um dia irritasse uma mulher", diz a canção, seria "um tolo" se esperasse dela "qualquer misericórdia". Pois a mulher é caracterizada por "orgulho, raiva e desconsideração pelo perdão", bem como "engano e crueldade". Com a ajuda dessas características, a mulher "conquista seu desejo" em "tudo o que faz", e 
quando sente raiva ou ciúme, "sua força supera a força mortal" (Machiavelli, 1965, Clizia, canzone antes do ato 4, p. 847). É quase como se uma mulher mais velha vingativa se tornasse a fortuna, com poder sobre-humano sobre o desfecho dos acontecimentos no mundo dos homens.

Muitos desses temas se repetem em mais uma combinação na história ou fábula de Maquiavel, "Belfagor: o diabo que se casou”. O tema principal é que os tormentos do inferno são preferíveis àqueles infligidos pelo "sexo feminino”, particularmente por uma esposa megera (Machiavelli, 1965, "Belfagor", p. 869). Mais uma vez, há dois tipos de mulheres: filhas jovens e passivas, mas sedutoras, e esposas vingativas, mais velhas, embora, neste caso, os pares não sejam formados por mãe e filha, e sim por antes e depois. A tímida virgem se transforma na megera perigosa quando obtém poder sobre o homem por meio do amor e do casamento.

A história de "Belfagor" é esta. São tantos os homens que chegam ao inferno se queixando de que haviam sido levados para lá "por nada além do que ter-se casado" que os demônios decidiram testar a verdade dessa alegação (Machiavelli, 1965, "Belfagor”, p. 869). Um diabo é enviado de volta à Terra para se casar. Ele escolhe uma moça "muito bonita", a "filha" de um homem rico, mas logo fica "apaixonado demais por ela". Quando se dá conta de seu poder sobre ele, ela começa a "comandá-lo". Ela é mais arrogante do que Lúcifer, gasta todo o dinheiro do marido em roupas, dá-lhe ordens, "sem qualquer misericórdia ou consideração", e tem um "temperamento tão arrogante" que nem consegue manter servos (Machiavelli, 1965, "Belfagor”, p. 871). Na verdade, até os demônios que vieram do inferno como servos do marido preferem voltar para lá "e viver no fogo, em vez de ficar no mundo, sob comando dela”. O marido foge e, depois de novas aventuras, finalmente é enganado e levado a voltar para o inferno com o anúncio de que sua esposa está vindo buscá-lo. Ao mero som da palavra "esposa”, ele foge "aterrorizado", preferindo "voltar ao inferno (...) a, mais uma vez, com tamanho aborrecimento, ansiedade e perigo, colocar seu pescoço sob o jugo do casamento" (Machiavelli, 1965, "Belfagor", p. 877). Anteriormente, durante suas aventuras na Terra, o diabo entra e "possui" uma série de mulheres jovens. Apesar de uma dessas mulheres ser casada, todas são chamadas de "moças" ou "filhas" e, em todos os casos, é o pai da mulher que organiza o exorcismo (Machiavelli, 1965, "Belfagor”, p. 874-876). Mais uma vez, essas mulheres nada têm de pessoas; elas só aparecem com a finalidade de ser 
possuídas. Uma mãe, por outro lado, tem uma personalidade distinta e é realmente capaz de agir, mas está cheia de fúria, e é mais perigosa para o marido do que o próprio diabo.

A natureza funesta dessa fúria e desse perigo também aparecem em forma de não ficção no último capítulo, um tanto enigmático, dos Discursos. Ligando perigos aparentemente bastante díspares superados por Roma, o capítulo começa a sugerir o poder antipolítico subjacente à própria feminilidade. Sob o título, "De como uma república que se quer manter livre necessita de novos atos de previdência; e dos méritos que levaram Quinto Fábio a ser chamado de Máximo", o capítulo fala inicialmente de "emergências" nas quais uma cidade precisa de um "médico" (Machiavelli, 1965, p. 527). Estas ameaças ao corpo político são exemplificadas por uma ocasião na Roma antiga, "quando parecia que todas as esposas romanas tinham conspirado contra seus maridos para matá-los - de tantas que realmente os envenenaram e tantas que tinham se preparado para fazê-lo". A referência é a um incidente, em 331 a.C., quando muitos homens romanos importantes morreram durante uma epidemia, e uma garota escrava levantou a acusação de que eles tinham sido envenenados por matronas romanas. Vinte senhoras patrícias, encontradas fervendo algo sobre um fogo, foram obrigadas a tomar sua beberagem e morreram. Após uma investigação mais aprofundada, 170 matronas foram condenadas à morte (Livius, 1967, VIII, 18, 1. 1-13; Machiavelli, 1950, II, p. 214).

A seguir, Maquiavel menciona outro incidente posterior de envenenamento em Roma, no qual cerca de duas mil pessoas foram condenadas. Embora homens e mulheres estivessem envolvidos no caso, a conspiração do envenenamento envolveu ritos báquicos de caráter obsceno realizados em estabelecimentos noturnos romanos. Essas "emergências" só foram superadas, Maquiavel indica, pela disposição de Roma em punir um grande número de malfeitoras de formas "terríveis", como a dizimação, cujo próprio terror demonstrou a "grandeza daquela república e o poder de suas ações" (Machiavelli, 1965, p. 528).

Somente neste ponto é que o capítulo se volta a Quinto Fábio. Ele, na verdade, foi o único a quem a escrava denunciou a trama das matronas em 331 a.C. Mas Maquiavel não menciona isso, apresentando-o por meio de um incidente posterior em sua vida, envolvendo um tipo de perigo aparentemente não relacionado. "Através da liberalidade praticada pelos romanos ao dar 
cidadania a estrangeiros, foram tantos os filhos nascidos em famílias novas que, em pouco tempo, muitos deles obtiveram o direito de voto, a ponto de que a administração estava ficando duvidosa" e abandonando as antigas diretrizes e a antiga liderança. Quinto Fábio entendeu o perigo desse crescimento estranho dentro do corpo político, e isolou "todas aquelas novas famílias - a causa das dificuldades - em quatro tribos", para que "não pudessem infectar toda Roma" (Machiavelli, 1965, p. 528-529). Por isso, ele foi, e "mereceu ser" chamado de o maior: "Máximo" (Machiavelli, 1965, p. 529). O próprio Maquiavel chama as "emergências" reunidas neste capítulo de "estranhas", mas não deixa claro o que elas significam para ele. Parecem dizer respeito à introdução no corpo político de substâncias exóticas que ameaçam destruí-lo, a menos que um médico intervenha com medidas drásticas. Mas, às vezes, o veneno é literal, introduzido, em um caso, por mulheres em conspiração contra os seus homens, em outro, por pessoas ligadas a um culto centrado na voraz oralidade feminina; às vezes o veneno é simbólico, um elemento estranho introduzido inicialmente pela liberalidade romana em relação à cidadania, mas imediatamente interpretado em termos de fertilidade, a capacidade fértil das mulheres estrangeiras. Este último caso é remediado, como sugere o título do capítulo, pelo grande homem pronto para qualquer emergência. Porém, no primeiro caso, o que salva Roma é uma prontidão para a punição severa e terrível em grande escala, e não parece haver qualquer "médico" nem "atos de previdência" envolvidos. A punição aterrorizante é, de alguma forma, o equivalente funcional de um grande homem superando o veneno corruptor das mulheres? E por que um capítulo sobre os perigos feminino e sexuais deveria concluir os Discursos? Certamente não foi apenas o último item que sobrou após os outros materiais terem sido organizados.

A fonte mais rica, mas também a mais confusa, sobre as mulheres em relação à política é o longo poema inacabado de Maquiavel, "O asno [de ouro]", que mais uma vez apresenta o par formado por donzela e matrona, e que começa a estender a imagem de feminilidade do meramente humano a fêmeas de proporções míticas, incluindo a fortuna. Ele descreve uma versão da lenda de Circe, uma figura feminina sobre-humana que transforma homens em 
animais. ${ }^{7}$ Depois de um capítulo introdutório, a história propriamente dita começa na noite escura, em um lugar muito "bruto" e assustador. O narrador diz que não sabe como chegou a esse lugar onde "perdeu totalmente [sua] liberdade”, embora diga, pouco depois: "minha escassa sagacidade, minha vã esperança e minhas vãs opiniões me fizeram cair neste lugar” (Machiavelli, 1965, “[Golden] Ass”, II, 1. 22-24, 85-87, p. 753-754).

A atmosfera ameaçadora do lugar e um som altíssimo que de repente se ouviu de um chifre assustaram-no a ponto de "subjugar" seu "vigor [virtù]"; incapaz de ficar ereto, ele é forçado a se inclinar contra um tronco de árvore. Enquanto ele está, portanto, destituído de sua masculinidade, aparece uma jovem "de extrema beleza", carregando um chifre e uma lanterna, e conduzindo um rebanho de animais. A imagem de Diana foi invocada nas primeiras linhas do poema, mas essa jovem parece ser mais uma pastora do que uma caçadora. Ela explica que é uma das "muitas donzelas" a serviço de Circe, que governa um reino naquela floresta. Circe é "inimiga dos homens" e transforma qualquer um que encontre em animal, "tão logo olha fixo para o rosto dele" (Machiavelli, 1965, "[Golden] Ass”, II, 1. 36-37, 49-57, 110-141, p. 753-755). A jovem, pelo contrário, acaba por ter um "semblante amoroso" que brilha para o narrador "mais do que todos os outros rostos" (Machiavelli, 1965, “[Golden] Ass”, V, 1. 16-18, p. 762). Ela alerta o herói de que "quem vem aqui jamais escapa", mas mesmo assim se oferece para ajudá-lo a fazer exatamente isso. Ela irá protegê-lo contra Circe elhe revelará todos os segredos da rainha. Ela diz a ele que finja fazer parte do rebanho e, assim, de quatro, ele é levado ao palácio de Circe. Lá, ao contrário de Diana, que na mitologia é sempre uma figura virginal, a jovem passa a seduzir o herói, evocando sua virtù perdida (Machiavelli, 1965, "[Golden] Ass”, II, l. 112-113, p. 755; IV, 1. 112, 129, p. 761).

Em "O asno [de ouro]", a bela jovem, embora ainda seja objeto de desejo do herói, cumpre um papel muito ativo, até mesmo dominante, e tem uma personalidade desenvolvida. Ela o incentiva, ensina, alimenta e seduz, protegendo-o do poder de Circe, que o manteria cativo e dele retiraria a

Circe era filha de Hellos. Ela envenenou o marido, um rei, e foi morar na ilha de Aeaea. Feiticeira célebre por seus conhecimentos de magia, encantos maléficos e ervas venenosas, ela transformou em porcos os companheiros de Odisseu, mas foi superada por este e morta por Telêmaco, que se casou com a filha dela.

8 A frase é do Inferno de Dante. 
masculinidade. Ela e o herói conversam "de muitas coisas, como um amigo fala com outro", um grau de reciprocidade entre os sexos que não é sequer aproximado em qualquer outro lugar nas obras de Maquiavel (Machiavelli, 1965, “[Golden] Ass”, VI, 1. 22-24, p. 764). No entanto, mesmo essa mulher tem o herói cativo no quarto dela, e ele, "entregando-se" ao poder dela, desmaia, "todo prostrado em seu seio doce" (Machiavelli, 1965, "[Golden] Ass", IV, 1. 140-142, p. 761). A presença dela também o impede de "refletir" e, particularmente, de refletir sobre política.

$\mathrm{Na}$ verdade, "O asno [de ouro]" é um poema muito mais complexo, de interesse muito maior para os nossos propósitos do que o sugerido até agora. Ele não apenas diz respeito às relações entre os sexos, mas conecta explicitamente o assunto a questões de ordem política, embora sua mensagem política esteja longe de ser óbvia. A própria Circe é uma figura política, uma "rainha", que "governa seu reino" (Machiavelli, 1965, "[Golden] Ass", II, 1. 116, 138, p. 755). Mas se enfatiza muito o contraste entre o seu mundo feminino natural e o mundo dos homens, que é político e produto do artifício humano. Circe só foi morar em seu palácio na floresta, segundo nos é dito, depois de ser forçada "a abandonar seu antigo ninho, antes de Jove assumir o domínio [lo stato]", e só depois de não conseguir encontrar refúgio entre os seres humanos, "tão grande era o rumor sobre sua infâmia" (Machiavelli, 1965, “[Golden] Ass”, II, 1. 101-105, p. 755). Assim, ela se estabeleceu na floresta, "fugindo de toda a sociedade e lei humanas". Elá, vivendo como inimiga dos homens, captura todos os que encontra, privando-os da "liberdade" e, claro, literalmente os transformando da forma humana na animal (Machiavelli, 1965, "[Golden] Ass”, II, 1. 24, p. 753). Os homens mantidos em cativeiro por Circe vivem em dormitórios que se assemelham a um "convento" e são totalmente dependentes de cuidados femininos no "ninho" de Circe, sendo guardados e levados para fora diariamente para se alimentar, pela jovem serva (Machiavelli, 1965, “[Golden] Ass”, VI, 1. 41-42, p. 765; V, 1. 10, p. 761).

Toda a narrativa de Circe que conforma a maior parte do poema, aliás, está inserida em um quadro que justapõe animalidade e vida política. $\mathrm{O}$ prólogo introdutório abre com a declaração do narrador de que vai relatar o que lhe aconteceu enquanto estava na forma de um asno. Contudo, essa transformação em asno jamais ocorre, presumivelmente porque o poema é inacabado; em um determinado momento, a serva diz ao herói que ele 
terá de "viajar para explorar o mundo, coberto com uma pele diferente" (Machiavelli, 1965, “[Golden] Ass”, I, 1. 1-2, p. 750; III, 1. 116-117, p. 758). ${ }^{9}$

No prólogo, no entanto, o narrador realmente fala de si mesmo "zurrando" e com uma "natureza" de asno, e passa a contar uma "história", sugerindo o que essas referências podem significar e qual seria sua importância política. Nenhuma outra razão é apresentada para a inclusão dessa "história" aparentemente independente. A história trata de um jovem que, era uma vez, vivia em Florença e sofria de uma doença estranha: sem motivo aparente, de repente ele começava a correr descuidadamente pelas ruas. Seu pai experimentou muitas maneiras de curá-lo. Finalmente um "charlatão" fingiu tê-lo curado, mas ordenou que, durante quatro meses, não se lhe permitisse sair às ruas sozinho. Isso funcionou por um tempo, mas um dia, o jovem, chegando a um determinado canto, não pode mais "se conter, quando viu a rua tão reta e larga, e retomou seu antigo prazer" (Machiavelli, 1965, "[Golden] Ass", I, 1. 18, 103-108, 30-78, p. 750-751). Largou a capa, ignorou os apelos de seus companheiros ao bom senso e à honra, e gritou: "Nem Cristo pode me manter aqui", e saiu correndo. "Depois disso, correu sempre, enquanto viveu". A moral concluída pelo narrador é: "a mente do homem, sempre voltada ao que lhe é natural, não protege contra o hábito ou a natureza” (Machiavelli, 1965, “[Golden] Ass”, I, 1. 179-90, p. 752).

Mas qual é o significado dessa história, aparentemente não relacionada à lenda de Circe nem à metáfora do asno que zurra? O que quer dizer essa estranha compulsão de correr despreocupadamente pelas ruas de Florença? $\mathrm{O}$ asno, segundo o que nos diz o narrador, é um animal que morde e chuta, está acostumado a receber mordidas e golpes em troca disso, e tem sua própria compulsão: nem "os céus" podem lhe impedir "de zurrar". O próprio narrador parece compartilhar essas características, tendo tido que aprender a não "se importar com a mordida do caluniador" e não temer mordidas e golpes, "pois passei a ter a mesma natureza daquele a quem cantei". Como o asno não consegue deixar de zurrar e como o rapaz florentino não conseguia deixar de correr, o narrador diz que não consegue deixar de "falar mal" daqueles a quem conhece, espalhando "um pouco de veneno" por meio de suas revelações, vendo "o que é ruim mais rapidamente do que o que é bom" em seus semelhantes. Como o rapaz florentino, deu início a essas práticas

9 O prólogo parece inspirado em "O asno de ouro", de Apuleio (De Maria, 1899, p. 5). 
malévolas em sua infância, tendo "cedo voltado meus pensamentos a beliscar isso e aquilo"; mas parecia, por um tempo, ter desistido, ficando "bastante quieto e paciente", como um jumento obediente, "não mais observando os defeitos dos outros, e sim buscando, de alguma outra forma, avançar para acreditar que estava curado" (Machiavelli, 1965, "[Golden] Ass", I, 1. 17990 , p. 752). Mas a natureza acaba prevalecendo; como o rapaz florentino, o narrador recaiu, compelido pela "época atual, tão negativa e ruim", e pelo fato de que lhe foram negadas outras formas de "avançar". Como o asno, ele "tomou o seu rumo" no mundo, "subindo e descendo tantas escadas (...), a fim de ver a natureza de cada mortal", que não consegue deixar de zurrar a verdade, mordendo quem está ao seu redor (Machiavelli, 1965, “[Golden] Ass", I, 1. 179-90, p. 752).

Parece inevitável que o asno, como o rapaz que corria, represente outro rapaz florentino, o próprio Maquiavel, em seu exílio político; como aquele, tendo subido e descido tantas escadas de fundos nos palácios do mundo, tendo aprendido a suportar calúnia e outros golpes e mordidas, tendo negadas outras maneiras de avançar, ele dirá a verdade maliciosa sobre tudo o que sabe. Ele se apresenta sob o disfarce ridículo de um animal, a fim de ter, por assim dizer, licença para zurrar. ${ }^{10}$ Assim, o prólogo leva o leitor a esperar um poema satírico, em que vários dos contemporâneos de Maquiavel serão ridicularizados como animais. E, de fato, assim é o catálogo dos animais no sétimo capítulo do poema, embora, em sua forma inacabada, não se possam identificar as referências (Machiavelli, 1965, p. 767; De Maria, 1899).

Além disso, ainda que de forma mais hesitante, pode-se conectar o "correr pelas ruas" de Florença àquele "correr desordenadamente pelas ruas" de Roma, que Maquiavel elogia nos Discursos como uma manifestação de saúde política e um estímulo à liberdade romana, embora outros possam condená-lo como doença ou loucura (Machiavelli, 1965, p. 203). Ou se pode vincular à "prontidão" com a qual, Maquiavel nos diz nas Histórias florentinas, os cidadãos de Gênova "corriam juntos" nas ruas daquela cidade quando um patriota "gritava o nome da liberdade" (Machiavelli, 1965, p. 1241). Em Florença, por outro lado, quando Jacopo de’ Pazzi foi às ruas durante a conspiração Pazzi, "conclamando o povo e a liberdade", porque o povo tinha sido comprado pela "fortuna e a liberalidade" dos Médici, tinha sido

${ }^{10}$ Em uma carta do exílio reclamando a Vettori de como perdera o contato com os acontecimentos políticos, Maquiavel chama a si mesmo de asno (Machiavelli, 1965, p. 921). 
"ensurdecido", de modo que "a liberdade não era conhecida em Florença", e "não obteve resposta de quem quer que fosse" (Machiavelli, 1965, p. 1393). Pode ser, então, que, ao falar verdades maliciosas sobre tudo o que viu no mundo, Maquiavel também tenha sido tentado a correr despreocupadamente pelas ruas de sua cidade, gritando o nome da liberdade; mas, como o povo foi ensurdecido pelos Médici mais uma vez, seus gritos são apenas o zurrar de um asno, a compulsão de um rapaz doente. Em sua fúria e sua frustração, ele morde e chuta as pessoas por meio de um poema satírico; em sua forma disfarçada, pode escapar à vingança delas, embora seja incapaz de garantir sua liberdade.

Além do papel político ou antipolítico da própria Circe e das referências à política da Florença de Maquiavel que são evidentes no prólogo, o poema relaciona sua história manifesta com temas políticos em mais uma terceira forma. O quinto capítulo é uma longa reflexão sobre política, uma meditação do herói, deixado sozinho quando a jovem serva vai fazer seu pastoreio. Instruído a permanecer na segurança do quarto dela, mas já não "esquecido das coisas humanas" pela presença dela, o herói é atingido pela "flecha da reflexão", de cuja "ferida" ela o tinha "curado" temporariamente, e começa a pensar sobre o mundo da política (Machiavelli, 1965, "[Golden] Ass", IV, 1. 138, p. 761; V, 1. 22-24, p. 762). Especificamente, ele pensa sobre o que causa a ascensão e a queda de "reinos" e "povos antigos", e sua conclusão é: ambição, particularmente a ambição que não conhece limites - o fato de que "os poderosos, com seu poder, nunca são saciados". Todo mundo reconhece "essa transgressão" e suas consequências, a de que "este apetite destrói nossos Estados", mas, mesmo assim, "ninguém foge dela". Portanto, Florença não conseguiu compreender que sua segurança estava em não estender seu império longe demais, "que poder demais era prejudicial". A maneira certa para Florença viver seria como as cidades livres alemãs, "seguras por ter menos de dez quilômetros em torno se si”. Mas, como a ambição levou Florença à expansão ilimitada, a cidade, agora, "tudo teme" (Machiavelli, 1965, “[Golden] Ass", V, 1. 32-69, p. 762-763).

No entanto, certamente também foi a ambição que levou o narrador, incapaz de "avançar de outras maneiras", a zurrar e correr. A ambição sempre é ruim? A meditação do herói volta-se imediatamente à visão oposta. A ambição é uma forma de energia viril que promove o êxito: os reinos que "sempre" ascendem são os "empurrados à ação por energia [virtú] ou necessidade", 
desde que tenham salvaguardas adequadas contra os perigos que a ambição acarreta. Eles devem ser internamente unificados e governados por leis e costumes bons. E conclui com um ataque contra aqueles reformadores cristãos, talvez como Savonarola, que atribuem o declínio dos Estados à "usura ou a algum pecado da carne” e receitam "jejuns, esmolas e orações” (Machiavelli, 1965, “[Golden] Ass”, V, 1. 79-111, p. 763). O narrador afirma que, embora a religião seja necessária para a "unidade e a boa ordem" no Estado, Deus só ajuda a quem se ajuda. "Acreditar que, sem esforço de tua parte, Deus luta por ti, enquanto estás ocioso e de joelhos, já arruinou muitos reinos e muitos Estados” (Machiavelli, 1965, “[Golden] Ass”, V, 1. 115-117, p. 764). A meditação parece pedir, então, atividade e esforço, em vez de oração e reconhecimento da dependência; no entanto, reconhece que esse desejo de ação pode facilmente se tornar uma fome de poder após poder, que não conhece saciedade. Mas por que esses pensamentos estão prensados entre duas cenas de alcova no palácio de Circe? Qual é a ligação da ambição com a política, por um lado, e das relações entre homens e mulheres com a animalidade, por outro?

A agência que destrói o estado ampliado demais e o indivíduo superambicioso é feminina. O narrador chama essa agência de "fortuna" e a personifica como uma mulher de proporções míticas. Ela assoma por trás de todo o mundo do poema, como uma espécie de supermatriarca que está além até mesmo de Circe. Na primeira linha de "O asno [de ouro]", a fortuna é invocada como musa do poeta, e tanto o narrador quanto a jovem serva reconhecem sua sujeição a ela, embora sua relação com Circe fique indefinida (Machiavelli, 1965, “[Golden] Ass”, I, 3, p. 750; IV, 1. 6, p; 761). A serva aconselha o herói a não deixar que a fortuna saiba o quanto seus golpes o machucaram, a lhe mostrar um "rosto não maculado por lágrimas"; seu maior risco, parece, é ser destituído de sua virilidade e ser reduzido a uma criança que choraminga, pois "chorar sempre foi vergonhoso para um homem" (Machiavelli, 1965, "[Golden] Ass”, III, 1. 85-87, p. 757). Contra esse perigo, como contra o poder de Circe, a serva busca protegê-lo, evocando a virtù dele. E, assim como o narrador e o burro no prólogo, a fortuna morde: a ascensão e a queda de povos antigos é caracterizada como uma alternância de carícias e "beliscões" da fortuna (Machiavelli, 1965, "[Golden] Ass", V, 1. 31-33, p. 762). Mas a figura da fortuna recebe relativamente pouca atenção explícita em "O asno [de ouro]", e adiaremos o aprofundamento da discussão a seu respeito a fim de examinar mais plenamente as complexas 
relações entre política e natureza sugeridas no poema, e entre cada uma delas e a sexualidade.

Maquiavel nunca personifica explicitamente a natureza, mas fica claro que, nesse poema, o mundo feminino também é o mundo da mãe-natureza. Justaposto ao mundo masculino da lei e da liberdade, temos o mundo da floresta, onde os homens são transformados em animais e mantidos em cativeiro, em permanente dependência. Cada um é transformado no animal que melhor encarna sua personagem humana específica. Então, ao levar o herói para percorrer o zoológico de Circe, a jovem serva lhe mostra, sob "a luz que ocultara debaixo da vestimenta", a verdadeira natureza de cada homem cativo e, portanto, também a "natureza" geral "de nossa condição" (Machiavelli, 1965, “[Golden] Ass”, VII, 1. 8, p. 767; VI, 1. 30, p. 764). Ela lhe mostra os leões, homens transformados, que tinham corações "magnânimos e nobres", mas, com alguma ironia, acrescenta que "alguns deles são da sua cidade” (Machiavelli, 1965, “[Golden] Ass”, VI, 1. 55-57, p. 765). Em vez disso, à medida que avançam, o narrador fica sabendo "quantos", dos que ele um dia "considerara Fábios e Catões, revelaram-se ovelhas e carneiros", em sua natureza transformada, isto é, verdadeira (Machiavelli, 1965, "[Golden] Ass", VII, 1. 100-102, p. 765). Por fim, ela mostra ao narrador um porco coberto de "merda e lama", advertindo-o para que não tentasse atrair o porco para fora do seu lamaçal com o objetivo de fazê-lo "se transformar em homem", pois, diz ela, o porco "não desejaria" tal mudança. Ele passou a preferir sua condição animal, como o próprio porco confirma (Machiavelli, 1965, “[Golden] Ass", VII, 1. 124-125; VIII, 1. 1-3, p. 769).

É apenas o "amor-próprio" do narrador, diz o porco, que faz com que ele considere a condição humana superior à dos animais e a veja como única fonte de valor. O porco, por sua vez, afirma "sem a menor dúvida:" "Nossa condição" é "superior à sua" (Machiavelli, 1965, "[Golden] Ass", VIII, 1. 2425 , p. 770). Isso porque os animais vivem pelo instinto, em harmonia com a natureza. É "a natureza que nos ensina" o que fazer, "o que é cada planta, se inofensiva ou prejudicial" (Machiavelli, 1965, "[Golden] Ass”, VIII, 1. 46-54, p. 770-771). Além disso, os animais são mais virtuosos do que os homens modernos:

Entre nós, são realizadas ações e façanhas ousadas, sem esperança de triunfo ou outra fama, como 
acontecia entre os romanos que eram famosos. ...

Ainda vivem entre nós algumas bestas que, para escapar à prisão e aos grilhões, morrendo

conquistam glória e liberdade;

Se olhares com moderação, verás claramente que neste jogo, superamos o teu lado. Em Vênus passamos tempo curto e pouco, mas tu a segues sem limites, em todo tempo e lugar (Machiavelli, 1965, “[Golden] Ass”, VIII, 1. 76-93, p. 771).

Por fim, os animais são "amigos mais íntimos da natureza" do que o homem e compartilham o "vigor [virtü]" dela mais livremente. Eles estão satisfeitos com a comida que a natureza lhes oferece "sem arte", em vez de ter fome, como o homem, "daquilo que a Natureza não pode lhe proporcionar" (Machiavelli, 1965, “[Golden] Ass”, VIII, 1. 106-107, 94-96, p. 771-772). Não satisfeito, o homem precisa depender do artifício para suas necessidades; entre todos os animais, "só o homem nasce desprovido de qualquer proteção", nu e indefeso: "em prantos, ele começa sua vida”. E, se a natureza deu ao homem "mãos e fala" como ferramentas gêmeas de sua arte, junto com elas, também deu "ambição e avareza", cujo mal supera o bem das primeiras dádivas (Machiavelli, 1965, “[Golden] Ass”, VIII, 1. 121-132, p. 772; ver também 1965, p. 459). A natureza, inicialmente, e depois a fortuna, sujeitam o homem a incontáveis males, traem as inúmeras promessas que fizeram a ele. Nenhum animal tem "vida mais frágil" ou "desejo mais forte" pela vida, "medo mais desordenado ou loucura maior". Acossado por "ambição, licenciosidade, lamentação e avareza”, o homem é "morto, crucificado e saqueado" por seu semelhante, enquanto os animais nunca prejudicam a outros de sua própria espécie. E o porco reitera sua recusa a ser novamente transformado em ser humano, dizendo que vive "mais feliz" em lamaçal, onde está livre de "ansiedade” (Machiavelli, 1965, “[Golden] Ass”, VIII, 1. 136-151, p. 772).

Existe, portanto, uma ambivalência considerável nesse poema sobre os custos e as vantagens de ser homem. Circe fugiu da sociedade humana e da lei, mas, ainda assim, governa um reino. O porco afirma que os animais não apenas são mais naturais do que o homem, mas até mesmo o superam em virtudes cívicas: corajosos como os antigos romanos, mais moderados e contidos do que o homem moderno. A ambição e a virtú seriam dádivas da natureza ou o que eleva o homem para fora do mundo animal? O porco diz que não vai deixar esse mundo, onde é livre de ansiedade. No entanto, tudo 
o mais que nos é dito sobre os animais no palácio de Circe indica que eles são desprezíveis, e degenerados, cativos a contragosto e ansiosos para voltar à forma humana. As dificuldades interpretativas apresentadas por esses temas conflitantes levaram alguns comentadores a afirmar que há duas categorias diferentes de animais no poema: os saudáveis, que sempre foram animais e são nobres por natureza, e seres humanos transformados, que são doentes e aleijados. Faria sentido, mas não há evidências textuais disso. Pelo contrário, o porco que defende a nobreza animal é explicitamente identificado como um ex-humano transformado por Circe e está claramente falando sobre outros como ele próprio. Ele diz ao herói para "direcionar sua imaginação (...) a mim" e usa a primeira pessoa do plural durante seu elogio ao mundo animal: nós, os animais (anteriormente humanos), somos superiores aos homens.

Maquiavel não é o único escritor para o qual a lenda de Circe envolveu ambivalência sobre a conveniência relativa de ser masculino e adulto em detrimento de ser animal e infantil. Na verdade, o capítulo sobre o porco pode muito bem imitar o diálogo de Plutarco sobre "A razão dos animais irracionais", em que Ulisses discorre a Grilo, transformado em porco por Circe (Plutarch, 1909, V, p. 693-705). Na versão de Plutarco, também, o sentido geral da lenda de Circe, de que ser capturado e transformado em animal não é desejável, é surpreendentemente contrariado pela atitude do porco. $\mathrm{O}$ porco de Plutarco, como o de Maquiavel, recusa-se a ser restaurado à forma humana, considerando os animais mais corajosos, mais moderados e, em termos gerais, mais virtuosos do que o homem. Devemos também lembrar que o poema de Maquiavel está inacabado. Talvez ele ainda não tivesse notado a contradição ou, de qualquer forma, ainda não fosse capaz de resolvê-la; talvez seja realmente por isso que o poema foi deixado inacabado. Além disso, em sua forma atual, o poema nada nos diz sobre como o narrador foi transformado em asno e, mais tarde, essa transformação foi revertida: ele quis isso ou não? E por qual agência ele foi transformado? Suspeita-se de que Circe, mas também de que outra fêmea que assoma por trás dela, tenha privado o narrador de qualquer "outro caminho para avançar" além do "observar" malicioso e o "zurrar" asinino sobre os "defeitos" de outros homens. Essa mulher, a quem o narrador invoca como sua musa, é a mesma força que "impediu" o autor de A mandrágora "de mostrar outras forças [virtù] com outras ações" e que lançou sobre as costas do autor (do asno?) de O príncipe o "fardo de" sua "grande e constante malícia": a fortuna (Machiavelli, 1965, 
“[Golden] Ass”, I, 1. 94-96, 109, p. 752; Mandragola, prólogo, p. 778; 1960 1965, VIII, p. 58; 1965, p. 11).

De qualquer forma, os temas desse poema parecem bastante claros. Dizem respeito a homem e mulher, autonomia e dependência, maturidade e infância, humanidade e animalidade, artifícios políticos e natureza, ambição, agressividade e ansiedade. $\mathrm{O}$ ensinamento do poema sobre esses assuntos, no entanto, está longe de ser claro, pelo menos na ausência de um quadro teórico coerente sobre os pontos de vista gerais de Maquiavel em relação a esses temas.

As relações problemáticas do ser humano, masculino, artificial e político para com o natural e o feminino, e da ambição e da ação para com ambos, repetem-se como temas centrais em outros poemas de Maquiavel, particularmente nos tercetos sobre "Ingratidão ou inveja", sobre "Ambição" e sobre "Fortuna". Todas essas últimas abstrações, assim como o conceito de fortuna, têm gênero feminino em italiano; mas isso, por si só, é insuficiente para provar que Maquiavel ou qualquer outra pessoa personificasse a todas, ou a alguma em específico, como mulheres. ${ }^{11}$ Pode haver uma tendência psicológica entre os falantes de uma língua com marca de gênero, quando eles personificam uma abstração, a imaginar seu sexo de acordo com o gênero da palavra, mantidas as demais circunstâncias. Essa é uma questão empírica. Mas as demais circunstâncias muitas vezes não são iguais, e é muito comum nas línguas com marca de gênero que uma personificação tenha o sexo oposto ao gênero da palavra. Às vezes, os tradutores nos enganam nessas questões. Simplesmente escrevendo alguns substantivos abstratos em maiúsculas, eles podem sugerir uma personificação que pode ou não ter sido pretendida pelo autor original; e usando o pronome masculino e geral ou o feminino em inglês, em conexão com esses substantivos, é comum que sugiram o sexo de uma personificação, que, mais uma vez, pode corresponder ou não à intenção do autor. Sendo assim, devemos ser cautelosos em nossas afirmações. No caso de Maquiavel, no entanto, está claro, a partir dos textos, que essas

11 A própria palavra virtù é do sexo feminino. Assim como natureza, necessidade, occasione e acaso (sorte). Outra palavra para acaso (caso) é masculina, como são destino, engano (inganno), gênio (ingegno), céu e ócio. 
abstrações específicas são personificadas como femininas, e, especificamente, como mulheres poderosas de proporções míticas, que ameaçam os homens ou os governam.

Os “Tercetos sobre ingratidão" são, ainda mais explicitamente do que o prólogo de "O asno [de ouro]", uma meditação sobre as próprias "aflições" de Maquiavel. Estas resultam, naturalmente, das ações de determinados homens, mas tais ações foram motivadas pela intervenção de uma força chamada de "ingratidão", personificada no poema como feminina (Machiavelli, 1965, "Tercets on ingratitude", 1. 17-18, 24-25, p. 740). A ingratidão é "filha" da avareza e da suspeita. Além de pai e mãe, ela parece ter tido uma ama de leite que influenciou profundamente seu caráter; ela foi "amamentada nos braços da inveja”. Não nos é dito se o bebê alguma vez mordeu o peito que o amamentava, mas morder aparece repetidamente no poema. A ama de leite, a inveja, costuma ter "um dente", com o qual pode "morder" os homens, amaldiçoando o mordido a "viver como um descontente" para todo o sempre. Na verdade, tudo, em todos os lugares, é "perfurado e mordido" pelo "dente envenenado" da ingratidão da "ama" (Machiavelli, 1965, "Tercets on ingratitude”, 1. 25-26, 33, 1-2, 112-113, p. 740-742). Maquiavel foi vítima dela. A ingratidão, ela própria, não morde, mas (assim como o amor) atira em homens com flechas, mas suas flechas parecem transmitir a agressão oral associada à ama. Um homem atingido pela terceira e mais poderosa flecha da ingratidão "dilacera e morde seu benfeitor" para sempre (Machiavelli, 1965, “Tercets on ingratitude", 1. 40-54, p. 741).

Como em "O asno [de ouro]", essas imagens de agressão verbal estão ligadas diretamente a consequências políticas. A ingratidão faz seu "ninho", sua "morada principal”, em "peitos de príncipes e reis", embora, na verdade, "triunfe no coração de todos os governantes", sejam quem forem (Machiavelli, 1965, “Tercets on ingratitude", 1. 27-28, 61-62, p. 740-741; ver também 1965, p. 259). Em Estados onde o povo governa, ela "se deleita ainda mais no coração do populacho", pois o povo, sendo ignorante e distante em relação a assuntos políticos, é mais suscetível à suspeição e, portanto, à ingratidão: "Onde pouco se sabe, mais se suspeita”. A própria situação de Maquiavel e de seu ex-líder, Soderini, pode ser exemplo disso, mas o poema cita o exemplo antigo de Cipião, o africano, forçado ao exílio da vida pública pela ingratidão do povo romano (Machiavelli, 1965, “Tercets on ingratitude", 1. 62-129, p. 741-743; ver também 1965, p. 259). Cipião é caracterizado em linguagem 
extravagante, muito semelhante a um antepassado heroico de proporções míticas, mas, mesmo assim, até ele acabou sendo derrubado pelo poder feminino dominante da inveja, expresso tanto em sua mordida quanto (como o poder de Circe) em seu olhar. Embora Cipião fosse um homem sem igual, antigo ou moderno, ela não "temia lhe mostrar os dentes da sua loucura, e olhar para ele com as pupilas de seus olhos em chamas" (Machiavelli, 1965, "Tercets on ingratitude", 1. 112-114, p. 742).

Nos "Tercetos sobre a ambição", as figuras femininas perigosas são a ambição e a avareza. Embora as imagens de agressão oral estejam ausentes, essas figuras são personificadas como inveja e ingratidão, e, assim como a ingratidão, elas próprias são formadas por uma mulher ainda mais gravemente perigosa. Ambição e avareza, o poema diz, são "instintos naturais" no homem e "vieram ao mundo" juntamente com ele (Machiavelli, 1965, “Tercets on ambition", 1. 12, 79, p. 735, 737). No entanto, o poema também sustenta uma origem mais tardia para elas, mais de acordo com a doutrina cristã. A ambição e a avareza só apareceram depois que Deus fez o homem e depois que Adão e Eva foram expulsos do Jardim do Éden. Elas não foram criadas por Deus, mas por um "poder oculto, que se sustenta no céu, entre as estrelas que o céu, ao girar, encerra" (Machiavelli, 1965, "Tercets on ambition", 1. 13-25, p. 735-736). Como Circe e outras dessas fêmeas míticas, esse poder é, "ao ser do homem, de forma nenhuma, amistoso"; envia a ambição e a avareza como duas "fúrias" para viver entre os homens. Elas estão nuas e são investidas de "tal graça que, aos olhos de muitos, em graça e felicidade elas abundam", mas também se diz que têm quatro caras cada uma e oito mãos, permitindo "que te agarrem e vejam em qualquer direção a que se virarem" (Machiavelli, 1965, “Tercets on ambition”, 1. 27-36, p. 736). ${ }^{12}$ Diz-se explicitamente que essas graciosas e monstruosas fúrias femininas simbolizam a falta de limites dos desejos humanos, de modo que cada uma delas porta uma "urna sem fundo". Foram elas que jogaram Caim contra Abel, introduzindo “a primeira morte violenta (...) no mundo". Desde então, sua influência se tornou tão difundida que, atualmente, "não há razão para que os homens se arrependam de fazer o mal". Entre homens universalmente fracos, a fraqueza é a única política que funciona; a bondade levará a derrota e arrependimentos (Machiavelli, 1965, “Tercets on ambition”, 1. 41-63, p. 736).

${ }_{12}$ Comparem imagens medievais de fortuna que tem vários membros (Patch, 1974, p. 42-44). 
Mas é esse o ensinamento do poema? Nada disso: ele passa a mostrar, da forma mais eloquente, por que os homens podem, no entanto, "arrepender-se" do mal, e, particularmente, da ambição sem limites, ao "contemplar os sofrimentos dos outros" e perceberem as implicações para si (Machiavelli, 1965, “Tercets on ambition”, 1. 130-131, p. 738). Muito possivelmente com base em experiências de Maquiavel em Verona, em 1509, onde ele observou as consequências da guerra do Papa Júlio II e seus aliados contra Veneza, o poema narra vividamente:

... eventos estranhos, como nunca antes aconteceram no mundo! ...

Turvos de sangue estão as valas e os córregos, cheios de cabeças, de pernas, de braços, e de outros membros cortados e decepados.

Aves de rapina, bestas selvagens e cães são agora seus túmulos de família - Oh, repugnantes,

horríveis e antinaturais túmulos!

Para onde quer que vires teus olhos, verás a terra molhada de lágrimas e de sangue, e o ar cheio de

gritos, de soluços e suspiros (Machiavelli, 1965, "Tercets on ambition", 1. 132-159, p. 738,735 , nota introdutória).

Assim, os "instintos naturais" da ambição e da avareza produzem resultados "repugnantes, horríveis e antinaturais". Assim como acontece com o discurso do porco em "O asno [de ouro]", não é fácil discernir os custos e os benefícios da vida natural.

O ponto em que os horrores da guerra atingem a altura de "inaturalidade", além disso, está no ultraje da piedade para com parentes mortos, na violação dos "sepulcros de família". Toda a descrição do poema sobre os horrores da guerra, de fato, é preenchida com imagens de violência no seio da família:

Um homem está chorando pelo pai morto e uma mulher, pelo marido; outro homem, espancado e

nu, tu vês expulso em tristeza, de sua própria casa.

Oh, quantas vezes, quando o pai abraçou firme o filho nos braços, um único golpe perfurou o peito

de ambos! 
... a cada dia, muitas crianças nascem por cortes de espada no útero. À filha, tomada de tristeza, diz

a mãe: "Para que casamento infeliz, para que marido cruel eu te guardei!" (Machiavelli, 1965, “Tercets on ambition”, 1. 113-153, p. 738).

Quer essas profanações resultem dos instintos naturais indomados pela civilização, quer sejam obra de um "poder oculto" no "céu", diferente de Deus, o criador, e que está longe de ser "amistoso" para com o homem, de qualquer forma, elas parecem derivar de uma perigosa força mítica feminina. Pois a misteriosa força hostil nos céus parece ser, mais uma vez, a fortuna. $\mathrm{O}$ poema não faz explicitamente a identificação, mas diz, sim, que é por causa da ambição e da avareza que a condição dos homens, e a dos Estados, nunca é estável nem segura, que "uma desce e a outra sobe" eternamente - uma imagem que lembra muito a roda da fortuna (Machiavelli, 1965, "Tercets on ambition”, 1. 64, p. 736). Diante desses poderes, a maioria dos homens se resigna à passividade, acreditando que nada pode ser feito: "A maioria dos homens se deixa dominar pela Fortuna” (Machiavelli, 1965, “Tercets on ambition”, 1. 177, p. 739). Mas Maquiavel quer ensinar que eles não precisam fazer isso; eles têm recursos para controlar sua própria ambição sem limites. Se alguém "culpa a Natureza” pelas condições terríveis e sangrentas na Itália,

[Ele diz] que isso não desculpa nem justifica (...) pois a disciplina [educazion] pode compensar onde

a natureza deixar a desejar (Machiavelli, 1965, “Tercets on ambition”, 1. 112-114, p. 737; 1960-1965, VIII, p. 322).

A solução, então, parece ser aquela mesma punitividade que, no último capítulo dos Discursos, foi a solução dos romanos contra a conspiração assassina das esposas. A Itália floresceu nos tempos antigos, diz o poema, precisamente porque a "disciplina severa [fiera educazion]" se opôs naquele momento aos poderes da natureza ou da fortuna. A agente desses poderes, a ambição, não pode ser extirpada da alma humana, mas pode ser controlada por meio de "graça ou melhor governo [ordin]". Para o indivíduo, isso significa que

Uma vez que nenhum homem tem poder para tirá-la de si próprio, é necessário que o discernimento 
e o Sólido Intelecto, com Método e Vigor [ordine e ferocia], sejam os companheiros dela (Machiavelli, 1965, “Tercets on ambition”, 1. 117, p. 737, 1. 187, 163-165, p. 739; 1960-1965, VIII, p. 322-32413).

Porque, se a ambição se junta a "um coração bravo [feroce], um vigor bem armado [virtute]", com uma masculinidade que beira a ferocidade, dará a coragem individual, de modo que "para si, um homem raramente teme o mal". O mesmo para os Estados,

Quando, por sua própria natureza, um país vive descontrolado, e então, por acidente, é organizado e

estabelecido sob boas leis,

A ambição usa contra povos estrangeiros aquela violência que nem a lei nem o rei permitem que ela

use em casa (Machiavelli, 1965, “Tercets on ambition”, 1. 91-99, p. 737).

É por isso que, na guerra, "os problemas internos quase sempre cessam" quando os cidadãos cerram fileiras contra o inimigo estrangeiro. Para os Estados, então, os males da ambição que se manifestam em divisões internas podem, por meio da disciplina e das boas leis, ser convertidos em coragem na guerra. Mas o poema, definitivamente, reconhece os custos dessa solução: infligir no exterior a violência eliminada em casa. Um Estado que adota esse curso

... certamente continuará a perturbar os currais dos outros, onde quer que sua violência tenha

cravado a bandeira (Machiavelli, 1965, “Tercets on ambition", l. 100-102, p. 737)

E as ovelhas perturbadas, como sugere a metáfora, são vítimas inocentes no massacre, exatamente como aquelas cujos sofrimentos o poema tão eloquentemente descreve.

Assim, esse poema, como "O asno [de ouro]", parece ser uma desesperada meditação circular sobre os custos e os benefícios de ser humano, em vez de bestial, de ser ambicioso e político. E, uma vez mais, estes estão interligados a questões de masculinidade, ao perigoso poder das forças femininas, à es-

13 Gilbert exagera, no entanto, ao apresentar educazion como "disciplina". 
perança de superá-las por meio de disciplina e ferocidade masculinas, aos custos horríveis que isso acarreta.

Portanto, o poder da feminilidade é um tema complexo para Maquiavel, centralmente entrelaçado com preocupações políticas. As mulheres jovens são perigosas como objetos desejáveis, ameaçando debilitar os homens e os privatizar. As mulheres mais velhas, uxoriais e matronais, têm personalidade e capacidade de agência, mas os seus propósitos provavelmente serão malévolos, principalmente quando estiverem com raiva, o que acontece com frequência. Seus poderes, portanto, aproximam-se do sobre-humano e fazem encolher os dos homens.

Obviamente, as donzelas devem acabar se transformando, elas próprias, em matronas. Suspeita-se de que a transição seja mediada pelo conhecimento carnal. Uma vez iniciada na sexualidade adulta, a donzela se torna perigosa de uma nova forma, porque agora tem seus próprios desejos, tornou-se uma pessoa por si só. E seus desejos, em pouco tempo, tornam-se insaciáveis. Então ela aparece em duplo aspecto: como a megera furiosa, o virago que os homens temem, e como a matrona correta, subjugada pelos laços do casamento patriarcal. A Lucrécia antiga é como uma fêmea domesticada, pronta a se destruir para defender a honra masculina de seu marido contra os perigos da própria sexualidade dela. A Lucrécia moderna de A mandrágora, embora, na verdade, seja casada, é inicialmente "donzela", sem dúvida porque o velho e fraco Nícia nunca realmente a tenha iniciado na sexualidade. Uma vez iniciada por Calímaco, ela aparece como se tivesse "renascido", ela se tornou uma pessoa. Apesar de ainda não sentir raiva nem desejo de vingança, ela é imediatamente uma competente e obstinada maquinadora, e se suspeita de que a raiva perigosa venha em breve.

Não obstante, também pode haver um nível mais profundo e mais simbólico de relacionamento entre a jovem e a mais velha, em que a donzela é precedida, e não sucedida, pela matriarca. A virago, pode-se sugerir, não é meramente a mulher vivenciada por homens adultos como a esposa ressentida, mas também a mulher vivenciada por crianças pequenas como a mãe perigosa, que alimenta, mas também domina e ameaça engolir. As fêmeas mitológicas que Maquiavel retrata sugerem essa interpretação, tanto por seu tamanho e seu poder arrebatadores quanto por sua frequente associação com a oralidade (alimentação, amamentação, mordida, envenenamento), e a infância (ninhos). Diante desse infantilizante perigo matriarcal, uma liga- 
ção sexual com uma mulher mais jovem pode oferecer relativa segurança, afirmando a masculinidade do homem e seu afastamento gradual da dependência infantil. Mas essa segurança é apenas relativa, pois a ligação sexual, por sua vez, ameaça tornar o homem escravo do amor e ameaça transformar a mulher mais jovem em outra megera raivosa.

Nessas imagens de mulheres, Maquiavel parece justapor, de um lado, homens, autonomia, vida adulta, relações de reciprocidade, política, o vivere civile, a agência humana na história e a própria humanidade a, de outro lado, mulheres, infância, dependência, relações de dominação, natureza, poder do ambiente e das circunstâncias, instinto, corpo e animalidade. A autonomia humana e a civilidade são construtos masculinos dolorosamente conquistados do poder feminino corrosivo e continuamente ameaçados por ele. A ambição masculina e a sexualidade humana, no entanto, cumprem papéis ambíguos nessa luta, algumas vezes ajudando e, em outras, ameaçando os homens. Na verdade, os próprios homens são ambivalentes em relação à luta, tentados permanentemente pelo porco satisfeito que rola "sem ansiedade" em sua "merda e lama" (Machiavelli, 1965, "[Golden] Ass", VIII, 1. 151, p. 772, 1. 1-3, p. 769). Então, o poder feminino parece estar, em certo sentido, dentro dos próprios homens. Somente disciplina feroz e punições terríveis podem assegurá-los no empreendimento masculino de se tornar humanos e autônomos. No entanto, a personificação mais central e politicamente significativa do poder feminino por Maquiavel, na qual a matriarca perigosa e a donzela sexualmente atraente parecem estar combinadas, ainda não foi explorada, mas é uma figura de tal importância e deriva de uma tradição histórica tão longa e complexa que requer uma discussão própria ${ }^{14}$.

\section{Referências}

DE MARIA, Udo (1899). Intorno ad un poema satirico di Niccolò Machiavelli. Bolonha: Zamorani e Albertazzi.

FLAUMENHAFT, Mera J. (1978). “The comic remedy: Machiavelli's Mandragola”. Interpretation, v. 7, n. 2, p. 33-74.

FLEISCHER, Martin (1966). "Trust and deceit in Machiavelli's comedies". Journal of the History of Ideas, n. 27, p. 365-380.

LIVIUS, Titus (1967). The history of Rome. Tradução de B. O. Foster. 14 vols.

14 Aqui a autora remete ao capítulo 6 do mesmo livro, que dá sequência a esta discussão (N.R.T). 
Londres: Wiliam Heinemann; Cambridge: Harvard University Press. MACHIAVELLI, Niccolò (1950). The discourses of Niccolò Machiavelli. 2 vols. New Haven: Yale University Press.

(1960-1965). Opere. 8 vols. Milão: Feltrinelli.

(1965). The chief works and others. 3 vols. Durham: Duke University Press.

PATCH, Howard R. (1974). The goddess Fortuna in medieval literature. New York: Farrar, Straus and Giroux.

PLAUTUS (1985). Casina, em The comedies of Platus. Vol. 2. Londres: George Bell and Sons.

PLUTARCH (1909). Complete works. 6 vols. New York, San Francisco: Thomas Y. Crowell and Company.

POLYBIUS (1889). Histories. Londres, Nova York: Macmillan and Company. STRAUSS, Leo (1978). Thoughts on Machiavelli. Chicago: The University of Chicago Press.

TARLTON, Charles (1970). Fortune's circle. Chicago: Quadrangle.

WHITFIELD, John H. (1953). "Machiavelli and Castruccio”. Italian Studies, n. 8, p. 1-28 .

\section{Resumo:}

O texto é parte de uma análise mais ampla da teórica política Hanna Pitkin sobre as relações de gênero na obra de Nicolau Maquiavel. Apresenta uma análise das representações do feminino nos textos do autor florentino. Há um inventário detalhado, no artigo, de quais são as imagens das mulheres e como elas são mobilizadas. Com ele, Pitkin discute as implicações políticas dessas imagens. A oposição entre o masculino e o feminino é apresentada como um componente importante das compreensões do poder e do Estado em Maquiavel. Palavras-chave: Maquiavel, gênero, mulheres, Estado, poder.

\section{Abstract:}

The text is part of a broader analysis, by political theorist Hanna Pitkin, about gender in the studies written by Nicolau Maquiavel. It discusses the representations of the feminine in his texts. There is an accurate collection of images of women and an analysis of how they enter the issues focused by Maquiavel. Pitkin discusses the political effects of those images. The duality between masculine and feminine is presentes as an important feature in the understandings of power and State in Maquiavel.

Keywords: Maquiavel, gender, women, State, power. 